\title{
IMPROVING TOLERANCE OF CORTADERIA SELLOANA PLANTS TO IRRIGATION WATER DEFICIENCY BY USING ASCORBIC ACID
}

\author{
M.A. El-Ashwah \\ Ornamental Plants and Landscape Gardening Res. Dept., Hort. Res. Inst., ARC, Egypt
}

\begin{abstract}
In order to improve the ability of the Cortaderia selloana seedlings to withstand the shortage of irrigation water, a pot experiment was conducted at the Experimental Farm of Ornamental Plants and Landscape Gardening, Res. Dept., Hort. Res. Inst., ARC, Giza, Egypt during 2017/2018 and 2018/2019 seasons. Seedlings were irrigated with three irrigation levels at 100\% (control), $75 \%$ and $50 \%$ of pot capacity (PC) and sprayed with ascorbic acid (AsA) at concentrations of $0,100,150$ and $200 \mathrm{ppm}$. The results showed that the shortage of irrigation water led to a gradual decrease in all vegetative, flowering and root characteristics as well as the contents of total carbohydrates and chlorophylls, this was accompanied with more accumulation of proline in leaves. Regarding foliar spraying with ascorbic acid, there was an increment in vegetative, floral and root characteristics due to increasing AsA concentrations until reaching the maximum growth rate at a concentration of $200 \mathrm{ppm}$. There were no significant differences between the effect of AsA at 150 or $200 \mathrm{ppm}$ in most cases, as it led to increase leaf carbohydrates, total chlorophyll, and proline, and it also increased the leaf content of total carbohydrates, total chlorophylls and proline. The interaction between
\end{abstract}

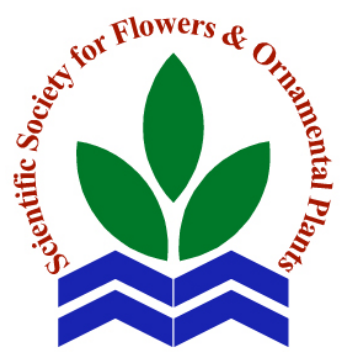

Scientific J. Flowers \& ascorbic acid and levels of irrigation water treatments cleared that AsA Ornamental Plants, application at 150 or $200 \mathrm{ppm}$ ameliorated the adverse effects of lack 7(4):363-377 (2020). of irrigation water on shoots, flowers and root growth. The best results

Received: of growth and flowering were obtained with AsA at 150 and 200 ppm 27/9/2020

Accepted:

$25 / 10 / 2020$ for plants irrigated with $100 \%$ then $75 \%$ PC with no significant differences in most cases, while the interaction between irrigation level $50 \%$ and ascorbic acid at $200 \mathrm{ppm}$ led to the highest accumulation of proline in leaves. In addition, the interaction between PC at $100 \%$ (control) and AsA at $200 \mathrm{ppm}$ achieved the best values of total carbohydrates and total chlorophylls in leaves. Accordingly, it could be recommended to irrigate Cortaderia selloana seedlings grown in pots with $75 \%$ of the pot capacity once every three days, with spray plants with ascorbic acid solution at 150 ppm every three weeks intervals, as this treatment was economical to save $25 \%$ of the applied irrigation water with maintaining high quality plants.

Key words: Cortaderia selloana, ascorbic acid, water deficiency, vegetative growth, flowering.

\section{INTRODUCTION}

Cortaderia selloana (Schult. \& Schult.f.) Asch. \& Graebn. (Fam. Poaceae) is an evergreen grass native to South America and New Zealand, it is a large, densely tufted, perennial grasses, with common name "pampas grass”, forming large clumps, 1.8- 
$3.7 \mathrm{~m}$ high, the lower internodes are short, the upper ones are very long. Foliage is glaucous green, medium in texture, mostly crowded at the base of the culm; upper leaves 0.3-2.5 $\mathrm{m}$ long, Staminate inflorescence a branched, oblong, panicle 60$70 \mathrm{~cm}$ long, about 20-30 cm wide, the branches erect or ascending and spreading, bearing spikelets nearly to the base, the inflorescence is usually white, beige or offwhite. Flowering and fruiting occur from early June until frost in the native area. Cortaderia selloana can used in lawns, in rock and water gardens, and around swimming pools and patios; it acts as a screen along driveways and property lines, it is excellent source of cut flowers when the inflorescence has attained its maximum size and brilliance in color; the mature panicles are useful in dried arrangements, (Oakes, 1990).

Water shortage is a major limitation for the production of agricultural crops (Razaji et al., 2012). Drought is considered as a major physical parameter of environmental constraints, which determines the success or failure of plant establishment. It has various deleterious effects on plant growth and development that limits the yield potential of different crops. Water shortage may cause changes in chlorophyll content, damage to the photosynthetic apparatus and cell death (Hameed et al., 2012). Drought stress can negatively affect the yield of various foods and crops, by influencing their physiobiochemical features (Chai et al., 2015 and Vurukonda et al., 2016). Drought stress can directly affect photosynthesis, development, nutrient uptake/accumulation and osmotic adjustment, ultimately causing a marked suppression in crop yield (Masih et al., 2014 and Chai et al., 2015).

Many enzymatic and non-enzymatic antioxidants accumulate to a considerable level in stressed plants to counteract ROS (Ashraf, 2009).

Adverse environmental factors such as drought and salinity stresses result in a considerable yield loss of crop plants all over the world. These abiotic stresses elicit complex cellular responses in the plant system, resulting in the production of excessive reactive oxygen species (ROS) such as hydrogen peroxide $\left(\mathrm{H}_{2} \mathrm{O}_{2}\right)$, hydroxyperoxyl $(\mathrm{HO})$, superoxide $\left(\mathrm{O}_{2}-\right)$ and singlet oxygen $\left({ }^{1} \mathrm{O}_{2}\right)$ radicals. Excessive ROS generated in plant cells tends to interact with different macromolecules resulting in oxidation of proteins, membrane lipids and nucleic acids and causes cellular damage, ultimately affecting the growth and productivity of plants (Wang et al., 2003). To protect themselves from adverse conditions, plants have evolved a number of cellular defense mechanisms including antioxidants such as ascorbate, as well as ROS-detoxifying enzymes such as superoxide dismutases, peroxidases and catalases (Inzé and Van Montagu, 1995 and Noctor and Foyer, 1998).

Ascorbic acid is commonly known as vitamin $\mathrm{C}$ and it is well known to regulate stress tolerance in plants as reported in a number of studies, e.g., canola (Shafiq et al., 2017) and maize (Dolatabadian et al., 2010). Among the plant antioxidants, L-ascorbate is a major antioxidant playing a vital role in the mitigation of excessive ROS activity through enzymatic as well as nonenzymatic detoxification (Mittler, 2002). It also acts as a cell signaling modulator in numerous cellular processes including cell division, cell expansion and cell wall growth (Conklin and Barth, 2004; Wolucka et al., 2005 and Zhang et al., 2007). Recently, it has been reported that ascorbate plays a crucial role in protection against various environmental stresses such as, drought (Hemavathi et al., 2011), salinity (Zhang et al., 2011; Venkatesh et al., 2012), low/high temperatures (Larkindale et al., 2005) and high light intensity (Talla et al., 2011).

\section{MATERIALS AND METHODS}

A pot trial was performed under open field conditions at the Experimental Farm of Ornamental Plants and Landscape Gardening, Res. Dept., Hort. Res. Inst., ARC, Giza, Egypt through 2017/2018 and 2018/2019 seasons to 
investigate the effect of ascorbic acid on Cortaderia selloana grown under different levels of irrigation water.

Transplants of Cortaderia selloana (One tiller, 90-100 cm height with 16-18 leaves) were obtained from local nursery in AlQanatir Al-Khayriyyah, Qalyubia Governorate, Egypt.

The transplants were immediately planted in both seasons in 30-cm diameter plastic pots filled with about $5.5 \mathrm{~kg} /$ pot of the loamy soil. Physical and chemical properties of the soil are shown in Table (a).

\section{Treatments:}

The seedlings were received the following treatments from mid of August:

1. Three irrigation levels, water holding capacity of pot soil was estimated for pot as $100 \%=840.0 \mathrm{~cm}^{3}, 75 \%=630.0 \mathrm{~cm}^{3}$ and $50 \%=420.0 \mathrm{~cm}^{3}$.). The pot capacity was calculated according to Brown (2002). The plants were irrigated once every 3 days (plants irrigated 140 times from the beginning to the end of the experiment). The amount of applied water per pot and per season are shown in Table (b).

2. Ascorbic acid (AsA) was applied as foliar sprays at $0,100,150$ and 200 ppm every 3 weeks.

3. All ascorbic acid treatments were combined with the different irrigation levels to create 12 interaction treatments.
The seedlings were received the above treatments till the experiment was terminated 14 months later (on October, $15^{\text {th }}$ ).

A factorial experiment based on a complete randomized block design, replicated thrice with 4 plants per replicate was accomplished in both seasons according to Gomez and Gomez (1984).

The plants under various treatments were fertilized every two weeks with 2 g/pot of commercial chemical fertilizer "Flowering Spring” produced by Agrico International Co.), containing $20 \mathrm{~N}: 20 \mathrm{P}: 20 \mathrm{~K}+$ micronutrients and the other agricultural practices were undertaken whenever needed, as usually grower did.

Data recorded:

\section{Vegetative growth parameters:}

Plant height $(\mathrm{cm})$ (average length of tillers), average number of leaves/tiller, number of tillers/plant, vegetative fresh and dry weights (average tillers fresh and dry weights), roots fresh and dry weights, and drought damage on vegetative growth (visual score), a reference scale (visual score) from 0 to 5 was used according to Sun et al. (2015).

\section{Flowering specifications:}

Number of days till flowering, number of inflorescences/plant, spike length [from pot surface to end of the inflorescence (m)], spike weight (g) and diameter of the inflorescence $[15 \mathrm{~cm}$ from the base of the inflorescence $(\mathrm{cm})]$.

Table a. Physical and chemical analyses of the used soil.

\begin{tabular}{|c|c|c|c|c|c|c|c|c|c|c|c|c|c|}
\hline \multirow{2}{*}{ Soil type } & \multicolumn{3}{|c|}{$\begin{array}{c}\text { Particle size } \\
\text { distribution (\%) }\end{array}$} & \multirow{2}{*}{ S.P. } & \multirow{2}{*}{$\begin{array}{l}\text { E.C. } \\
\text { (dS/m) }\end{array}$} & \multirow{2}{*}{$\mathbf{p H}$} & \multicolumn{4}{|c|}{ Cations (meq/l) } & \multicolumn{3}{|c|}{ Anions (meq/l) } \\
\hline & Sand & Silt & Clay & & & & $\mathrm{Ca}^{++}$ & $\mathbf{M g}^{++}$ & $\mathbf{N a}^{+}$ & $\mathbf{K}^{+}$ & $\mathrm{HCO}_{3}$ & $\mathrm{Cl}^{-}$ & $\mathrm{SO}_{4}^{--}$ \\
\hline Loamy & 48.0 & 35.5 & 16.5 & 44.0 & 1.36 & 8.28 & 3.5 & 2.5 & 6.63 & 0.65 & 0.5 & 7.5 & 5.28 \\
\hline
\end{tabular}

Table b. Amount of applied irrigation water during the experiment period.

\begin{tabular}{cccc}
\hline $\begin{array}{c}\text { Pot capacity } \\
\mathbf{( \% )}\end{array}$ & $\begin{array}{c}\text { Water amount/pot } \\
\left(\mathbf{( c m}^{\mathbf{3}}\right)\end{array}$ & $\begin{array}{c}\text { Number of } \\
\text { irrigations/season }\end{array}$ & $\begin{array}{c}\text { Water amount/pot/season } \\
\mathbf{( L )}\end{array}$ \\
\hline $\mathbf{1 0 0}$ & 840 & 140 & 117.6 \\
$\mathbf{7 5}$ & 630 & 140 & 88.2 \\
$\mathbf{5 0}$ & 420 & 140 & 58.8 \\
\hline
\end{tabular}




\section{Chemical composition:}

At the end of the second season, chemical composition analysis was carried out as following:

1. Total carbohydrates (\% in dry matter) according to Dubois et al. (1956).

2. Photosynthetic pigments (total chlorophylls a + b); mg/g F.W.): was determined according to the method described by Wellburn and Lichtenthaler, (1984).

3. Free proline content was colorimetrically estimated in dry leaf samples according to Bates et al. (1973).

\section{Statistical analysis:}

All obtained data were statistically analyzed according to the technique of analysis of variance (ANOVA) for a complete randomized block design in a factorial experiment as published by Gomez and Gomez (1984) by using "MSTAT-C" computer software package (MSTAT Development Team, 1989). Means of all treatments were compared using Duncan's multiple range tests at 5\% level of probability as described by Duncan (1955).

\section{RESULTS}

Effect of irrigation levels, ascorbic acid (AsA) rates and their interactions on:

\section{Vegetative growth parameters:}

Data in Table (1) show that treated plants were affected significantly. The decrease in the amount of irrigation water led to a significant decrease in all characteristics of plant growth, as plant height, number of tillers/plant and number of leaves/tiller decreased progressively with decreasing

Table 1. Effect of irrigation level, ascorbic acid and their interaction on plant height, number of tillers/plant and number of leaves/tiller of Cortaderia selloana plants during 2017/2018 and 2018/2019 seasons.

\begin{tabular}{|c|c|c|c|c|c|c|c|c|c|c|}
\hline \multirow[b]{2}{*}{$\begin{array}{c}\text { Water level } \\
\text { (\% pot } \\
\text { capacity) }\end{array}$} & \multicolumn{10}{|c|}{ Ascorbic acid (ppm) } \\
\hline & $\begin{array}{c}\text { Control } \\
\text { (0) }\end{array}$ & 100 & $\begin{array}{c}150 \\
2017 / 2018 \\
\end{array}$ & 200 & Mean & $\begin{array}{c}\text { Control } \\
\text { (0) }\end{array}$ & 100 & $\begin{array}{c}150 \\
2018 / 2019\end{array}$ & 200 & $\begin{array}{c}\text { Mean } \\
\text { (A) }\end{array}$ \\
\hline & \multicolumn{10}{|c|}{ Plant height (m) } \\
\hline Control (100) & $2.36 \mathrm{c}$ & $2.40 \mathrm{~b}$ & $2.57 \mathrm{a}$ & $2.58 \mathrm{a}$ & $2.48 \mathrm{a}$ & $2.56 \mathrm{c}$ & $2.66 \mathrm{~b}$ & $2.78 \mathrm{a}$ & $2.79 \mathrm{a}$ & $2.70 \mathrm{a}$ \\
\hline 75 & $2.13 \mathrm{e}$ & $2.18 \mathrm{~d}$ & $2.37 \mathrm{bc}$ & $2.38 \mathrm{bc}$ & $2.27 \mathrm{~b}$ & $2.33 \mathrm{e}$ & $2.40 \mathrm{~d}$ & $2.56 \mathrm{c}$ & $2.61 \mathrm{bc}$ & $2.48 \mathrm{~b}$ \\
\hline 50 & $1.93 \mathrm{~g}$ & $2.03 \mathrm{f}$ & $2.12 \mathrm{e}$ & $2.21 \mathrm{e}$ & $2.07 \mathrm{c}$ & & $1.12 \mathrm{f}$ & $2.30 \mathrm{e}$ & $2.35 \mathrm{e}$ & $2.20 \mathrm{c}$ \\
\hline \multirow[t]{2}{*}{ Mean (B) } & $2.14 \mathrm{c}$ & $2.21 \mathrm{~b}$ & $2.36 \mathrm{a}$ & $2.39 \mathrm{a}$ & & $2.31 \mathrm{c}$ & $2.39 \mathrm{~b}$ & $2.55 \mathrm{a}$ & & \\
\hline & \multicolumn{10}{|c|}{ Number of tillers/plant } \\
\hline Control (100) & & & $20.00 \mathrm{a}$ & 20.33 a & & & $19.33 \mathrm{~b}$ & $21.83 \mathrm{a}$ & & $20.28 \mathrm{a}$ \\
\hline 75 & $14.20 \mathrm{e}$ & $15.83 \mathrm{~d}$ & $19.67 \mathrm{a}$ & $19.67 \mathrm{a}$ & $17.34 \mathrm{~b}$ & $15.33 \mathrm{~g}$ & $17.00 \mathrm{~d}$ & $21.33 \mathrm{a}$ & $21.50 \mathrm{a}$ & $18.79 \mathrm{~b}$ \\
\hline 50 & $11.50 \mathrm{~h}$ & $12.67 \mathrm{~g}$ & $14.67 \mathrm{f}$ & 15.50 de & $13.58 \mathrm{c}$ & $12.40 \mathrm{i}$ & $14.27 \mathrm{~h}$ & $16.10 \mathrm{ef}$ & $16.37 \mathrm{e}$ & $14.78 \mathrm{c}$ \\
\hline \multirow[t]{2}{*}{ Mean (B) } & $14.29 \mathrm{c}$ & $15.61 \mathrm{~b}$ & $18.11 \mathrm{a}$ & $18.50 \mathrm{a}$ & & $15.27 \mathrm{c}$ & $16.87 \mathrm{~b}$ & $19.75 \mathrm{a}$ & $19.91 \mathrm{a}$ & \\
\hline & \multicolumn{10}{|c|}{ Number of leaves/tiller } \\
\hline Control (100) & $28.30 \mathrm{c}$ & $30.27 \mathrm{~b}$ & 33.37 a & 33.73 a & $31.42 \mathrm{a}$ & 31.33 c & $32.66 \mathrm{~b}$ & 35.66 a & 36.20 a & $33.96 \mathrm{a}$ \\
\hline 75 & $25.27 \mathrm{e}$ & $26.23 \mathrm{~d}$ & 33.30 a & $33.57 \mathrm{a}$ & $29.59 \mathrm{~b}$ & $25.67 \mathrm{e}$ & $27.67 \mathrm{~d}$ & $35.70 \mathrm{a}$ & $36.16 \mathrm{a}$ & $31.30 \mathrm{~b}$ \\
\hline 50 & $20.57 \mathrm{~h}$ & $21.90 \mathrm{~g}$ & $22.80 \mathrm{f}$ & $23.17 \mathrm{f}$ & $22.11 \mathrm{c}$ & $21.00 \mathrm{~g}$ & $21.40 \mathrm{~g}$ & $22.33 \mathrm{f}$ & $22.67 \mathrm{f}$ & $21.85 \mathrm{c}$ \\
\hline Mean (B) & 24.71 c & $26.13 \mathrm{~b}$ & 29.82 a & 30.16 a & & $26.00 \mathrm{c}$ & $27.24 \mathrm{~b}$ & $31.23 \mathrm{a}$ & $31.68 \mathrm{a}$ & \\
\hline
\end{tabular}

Means having the same letter are not significantly differed at 0.05 level of probability according to Duncan's Multiple Range Test (Duncan, 1955). 
irrigation level. The least values occurred at the lowest level (50\%) of pot capacity (PC), compared to plants irrigated with control (100\% PC which recorded the highest values (2.48 and $2.70 \mathrm{~m}$ for plant height, 19.96 and 20.28 for number of tillers/plant and 31.42 and 33.93 for number of leaves/tiller, in both seasons, respectively).

Concerning the effect of ascorbic acid (AsA), the same data in Table (1) indicated that there were increases in all data by increasing AsA doses. It is noticed that there were no significant differences between AsA at 150 and $200 \mathrm{ppm}$, the maximum values were a result of increasing AsA dose to by the highest dose (200 ppm), where the values were 2.39 and $2.58 \mathrm{~m}$ for plant height, 18.50 and 19.91 for number of tiller and 30.16 and 31.68 for number of leaves/tiller in the $1^{\text {st }}$ and $2^{\text {nd }}$ seasons, respectively.

The interactions between PC and AsA treatments also exerted a marked effect on studied treats as shown in Table (1), where the plants received AS at either 150 or 200 ppm and irrigated with $100 \%$ (control) or $75 \%$ PC gave the highest significant values as compared with the other treatments, in the two seasons, with the superiority of the combined treatment of $100 \%$ PC + AsA at $200 \mathrm{ppm}$, as it gave the highest records (2.58 and $2.79 \mathrm{~m}$ for plant height, 20.33 and 21.86 for number of tillers/plant and 33.73 and 36.20 for number of leaves/plant in the $1^{\text {st }}$ and $2^{\text {nd }}$ seasons, respectively). In all measurements, generally, the gradual decrement in irrigation water PC was accompanied by a progressive suppress in growth rate, which was improved by the gradual increase in AsA dose.

Data averaged in Table (2) show that increasing irrigation water amount to $100 \%$ PC, improved vegetative and root fresh and dry weights compared to $75 \%$ and $50 \%$ PC, reaching to the highest values (180.75 and $195.25 \mathrm{~g}$ for vegetative fresh weight, 61.71 and $60.62 \mathrm{~g}$ for vegetative dry weight, 1.442 and $1.388 \mathrm{~kg}$ for root fresh weight and 0.478 and $0.446 \mathrm{~kg}$ for root dry weight, in both seasons, respectively).
Concerning the effect of AsA application, (Table, 2) it was found that treating plants with higher levels of AsA showed an increase in the fresh and dry weights of shoot and root growth, as treating plants with AsA at 200 ppm achieved the highest values (181.67 and $185.11 \mathrm{~g}$ for vegetative fresh weight, 62.36 and $61.70 \mathrm{~g}$ for vegetative dry weight, 1.463 and 1.390 $\mathrm{kg}$ for root fresh weight and 0.423 and 0.393 $\mathrm{kg}$ for root dry weight in the $1^{\text {st }}$ and $2^{\text {nd }}$ seasons, respectively.

Regarding effect of the interaction, data in Table (2) show that AsA at 150 and 200 ppm combined with water regime at $100 \%$ or $75 \%$ PC were the best treatments with no significant differences effects between them on vegetative and roots fresh weights, meanwhile the interaction $100 \%$ PC and AsA at 200 ppm was the best significant affection on vegetative and roots dry weights compared with the other interactions. It gave (200.33 and $206.33 \mathrm{~g}$ for vegetative fresh weight/tiller, 71.60 and $68.53 \mathrm{~g}$ for vegetative dry weight/tiller, 1.527 and 1.462 $\mathrm{kg}$ for root fresh weight/plant and 0.512 and $0.475 \mathrm{~kg}$ for root dry weight/plant in the first and second seasons, respectively). It can also observed that treating plants with AsA improved fresh and dry weights of vegetative growth and roots for plants grown under limited water amounts.

\section{Visual score:}

Fig. 1 show that low irrigation level (50\% PC) recorded the lowest value of visual score of Cortaderia plants (4.4 points), the outward appearance is still very well, despite the lack of vegetative and flowering characteristics due to the reduction of irrigation water.

On the other hand, the visual score of plants increased by increasing the concentration of ascorbic acid reached to maximum score (4.9 points) for plants treated with AsA at $200 \mathrm{ppm}$.

Referring to the interaction, foliar spraying with AsA increased plant quality under all irrigation levels reaching to 
Table 2. Effect of irrigation level, ascorbic acid and their interaction on vegetative fresh weight, vegetative dry weight, root fresh weight and root dry weight of Cortaderia selloana plants during 2017/2018 and 2018/2019 seasons.

\begin{tabular}{|c|c|c|c|c|c|c|c|c|c|c|}
\hline \multirow{3}{*}{$\begin{array}{c}\text { Water level } \\
\text { (\% pot } \\
\text { capacity) }\end{array}$} & \multicolumn{10}{|c|}{ Ascorbic acid (ppm) } \\
\hline & $\begin{array}{c}\text { Control } \\
\text { (0) }\end{array}$ & 100 & & 200 & Mean & $\begin{array}{c}\text { Control } \\
(0)\end{array}$ & 100 & & 200 & $\begin{array}{l}\text { Mean } \\
\text { (A) }\end{array}$ \\
\hline & \multicolumn{5}{|c|}{$2017 / 2018$} & \multicolumn{5}{|c|}{ 2018/2019 } \\
\hline & \multicolumn{10}{|c|}{ Vegetative fresh weight (g)/tiller } \\
\hline Control (100) & 155.33 c & $168.67 \mathrm{~b}$ & $198.67 \mathrm{a}$ & $200.33 \mathrm{a}$ & $180.75 \mathrm{a}$ & $183.00 \mathrm{c}$ & $188.33 \mathrm{~b}$ & $203.33 \mathrm{a}$ & $206.33 \mathrm{a}$ & $195.25 \mathrm{a}$ \\
\hline 75 & $145.00 \mathrm{~d}$ & $156.33 \mathrm{c}$ & $197.00 \mathrm{a}$ & $198.00 \mathrm{a}$ & $174.08 \mathrm{~b}$ & $163.00 \mathrm{e}$ & $170.00 \mathrm{~d}$ & $202.33 \mathrm{a}$ & $204.67 \mathrm{a}$ & $185.00 \mathrm{~b}$ \\
\hline 50 & $132.00 \mathrm{e}$ & $133.67 \mathrm{e}$ & $145.33 \mathrm{~d}$ & $146.67 \mathrm{~d}$ & $139.41 \mathrm{c}$ & $143.67 \mathrm{f}$ & $141.67 \mathrm{f}$ & $144.67 \mathrm{f}$ & $144.33 \mathrm{f}$ & $143.58 \mathrm{c}$ \\
\hline \multirow[t]{2}{*}{ Mean (B) } & $144.11 \mathrm{~b}$ & $152.89 \mathrm{~b}$ & $180.33 \mathrm{a}$ & $181.67 \mathrm{a}$ & & $164.89 \mathrm{~b}$ & $165.00 \mathrm{~b}$ & $183.44 \mathrm{a}$ & $185.11 \mathrm{a}$ & \\
\hline & \multicolumn{10}{|c|}{ Vegetative dry weight (g)/tiller } \\
\hline Control (100) & 49.68 e & $55.22 \mathrm{c}$ & 70.34 a & 71.60 a & 61.71 a & $51.06 \mathrm{e}$ & $56.38 \mathrm{c}$ & $66.51 \mathrm{~b}$ & 68.53 a & $60.62 \mathrm{a}$ \\
\hline 75 & $45.81 \mathrm{f}$ & $53.73 \mathrm{~d}$ & $68.29 \mathrm{~b}$ & 70.52 a & $59.59 \mathrm{~b}$ & $46.37 \mathrm{~h}$ & $54.85 \mathrm{~d}$ & $66.92 \mathrm{~b}$ & $67.27 \mathrm{~b}$ & $58.85 b$ \\
\hline 50 & $38.51 \mathrm{i}$ & $40.94 \mathrm{~h}$ & $44.00 \mathrm{~g}$ & $44.95 \mathrm{fg}$ & $42.10 \mathrm{c}$ & $41.22 \mathrm{j}$ & $43.81 \mathrm{i}$ & $47.76 \mathrm{~g}$ & $49.27 \mathrm{f}$ & $45.52 \mathrm{c}$ \\
\hline \multirow[t]{2}{*}{ Mean (B) } & $44.67 \mathrm{~d}$ & $49.97 \mathrm{c}$ & $60.88 \mathrm{~b}$ & 62.36 a & & $46.22 \mathrm{~d}$ & $51.68 \mathrm{c}$ & $60.40 \mathrm{~b}$ & $61.70 \mathrm{a}$ & \\
\hline & \multicolumn{10}{|c|}{ Roots fresh weight (kg)/plant } \\
\hline Control (100) & $1.336 \mathrm{c}$ & $1.396 \mathrm{~b}$ & $1.511 \mathrm{a}$ & 1.527 a & 1.442 a & 1.268 c & $1.361 \mathrm{~b}$ & 1.460 a & 1.462 a & $1.388 \mathrm{a}$ \\
\hline 75 & $1.221 \mathrm{f}$ & $1.232 \mathrm{e}$ & $1.510 \mathrm{a}$ & 1.519 a & $1.370 \mathrm{~b}$ & $1.184 \mathrm{f}$ & 1.203 e & 1.457 a & 1.460 a & $1.326 \mathrm{~b}$ \\
\hline 50 & $1.107 \mathrm{~g}$ & $1.131 \mathrm{e}$ & $1.261 \mathrm{~d}$ & $1.345 \mathrm{c}$ & $1.211 \mathrm{c}$ & $1.050 \mathrm{~h}$ & $1.105 \mathrm{~g}$ & $1.242 \mathrm{~d}$ & $1.246 \mathrm{~d}$ & 1.162 c \\
\hline \multirow[t]{2}{*}{ Mean (B) } & $1.222 \mathrm{~d}$ & $2.253 \mathrm{c}$ & $1.428 \mathrm{~b}$ & 1.463 а & & 1.169 c & $1.223 \mathrm{~b}$ & 1.386 a & 1.390 a & \\
\hline & \multicolumn{10}{|c|}{ Roots dry weight (kg)/plant } \\
\hline Control (100) & $0.444 \mathrm{~d}$ & $0.451 \mathrm{c}$ & $0.504 \mathrm{~b}$ & $0.512 \mathrm{a}$ & 0.478 a & $0.417 \mathrm{~d}$ & 0.427 c & $0.465 \mathrm{~b}$ & 0.475 a & $0.446 \mathrm{a}$ \\
\hline 75 & $0.357 \mathrm{~h}$ & $0.382 \mathrm{~g}$ & $0.415 \mathrm{f}$ & $0.423 \mathrm{e}$ & $0.395 \mathrm{~b}$ & $0.325 \mathrm{~h}$ & $0.343 \mathrm{~g}$ & $0.393 \mathrm{f}$ & $0.400 \mathrm{e}$ & $0.363 \mathrm{~b}$ \\
\hline 50 & 0.2361 & $0.283 \mathrm{k}$ & $0.328 \mathrm{j}$ & $0.335 \mathrm{i}$ & 0.295 c & $0.198 \mathrm{l}$ & $0.243 \mathrm{k}$ & $0.297 \mathrm{j}$ & $0.305 \mathrm{I}$ & $0.261 \mathrm{c}$ \\
\hline Mean (B) & $0.346 \mathrm{~d}$ & $0.372 \mathrm{c}$ & $0.416 \mathrm{~b}$ & $0.423 \mathrm{a}$ & & $0.313 \mathrm{~d}$ & $0.338 \mathrm{c}$ & $0.385 \mathrm{~b}$ & $0.393 \mathrm{a}$ & \\
\hline
\end{tabular}

Means having the same letter are not significantly differed at 0.05 level of probability according to Duncan's Multiple Range Test (Duncan, 1955).

excellent visual score (5.0 points) for plants received $100 \%+$ AsA at all concentrations and plants that received $75 \%$ PC + AsA at 100, 150 and 200 ppm (Fig., 1).

\section{Flowers parameters:}

Regarding the effect of irrigation levels, data in Table (3) showed that the decrease of irrigation levels led to early flowering, as plants irrigated at 50\% PC were the earliest in flowering, but this had the lowest number of inflorescences/plant and the smallest inflorescence diameter. The highest values were obtained in plants irrigated with control (100\% PC), recording (428.17 and 422.33 days till flowering, 11.95 and 12.74 for number of inflorescences/plant and 15.49 and $15.92 \mathrm{~cm}$ for inflorescence diameter in both seasons, respectively.

In addition, data in Table (3) show that the AsA application to Cortaderia plants influenced significantly the abovementioned traits, compared to untreated plants, in both seasons. There was a strong convergence between AsA at 150 and 200 ppm in most cases. The longest period of vegetative growth (428.44 and 423.89 days) until flowering, the highest number of inflorescences/plant (11.44 and 12.22) and the largest inflorescences diameter (15.66 


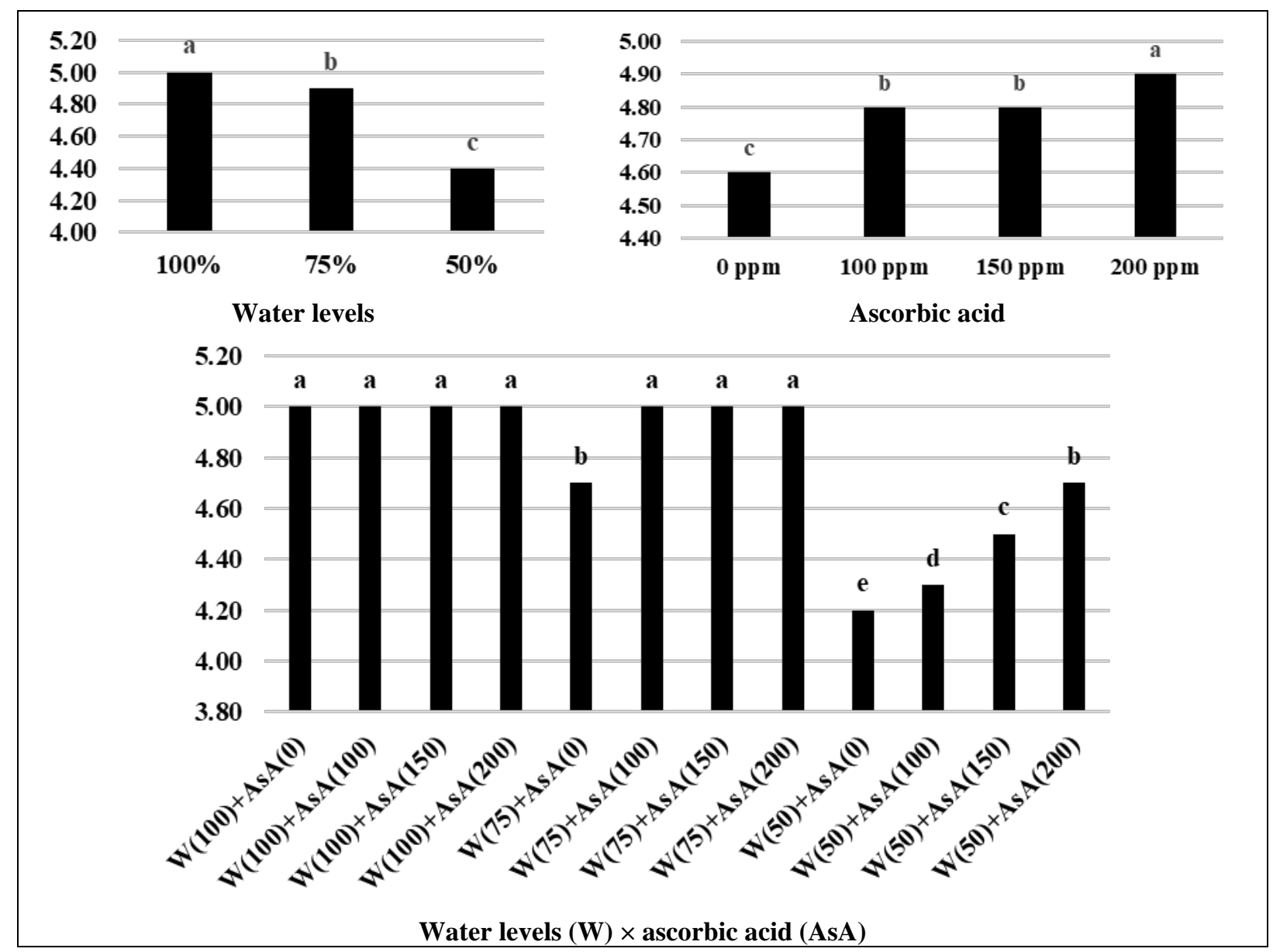

Fig. 1. Effect of water levels, ascorbic acid and their interaction on visual score of Cortaderia selloana plants during 2018/2019 season.

Means having the same letter are not significantly differed at 0.05 level of probability according to Duncan's Multiple Range Test (Duncan, 1955).

and $15.92 \mathrm{~cm}$ ), in both seasons respectively, were obtained with the application of AsA at 200 ppm.

Regarding the interaction effect, data in Table (3) show that increasing AsA concentration could alleviate the adverse effect of water shortage. The plants watered with 100\% PC (control) and AsA at 200 ppm recorded the highest values (436.00 and 430.00 days for number of days till flowering, 13.33 and 14.23 for number of inflorescences/plant and 16.67 and $16.57 \mathrm{~cm}$ for the inflorescence diameter in both seasons, respectively).

The data also indicated that there were no significant differences between spraying AsA at concentrations 150 or 200 ppm in plants watered at the level $100 \%$ PC or $75 \%$ PC, in most cases, and there was superiority for interaction irrigation with $75 \%$ PC and AsA at $150 \mathrm{ppm}$ compared with plants treated with irrigation level control (100\% PC) without the application of AsA.

Concerning the effect of irrigation levels on spike length and weight (Table, 4) the data show that, there was a reduction in spike length and spike weight with a decrease of the amount of irrigation water. The greatest values were 2.38 and $2.29 \mathrm{~m}$ for spike length and 167.8 and $166.0 \mathrm{~g}$ for spike weight in the $1^{\text {st }}$ and $2^{\text {nd }}$ seasons, respectively) for plants irrigated with $100 \%$ PC (control).

In addition, data in Table (4) showed a steady increase in spike length and weight with increasing doses of AsA with no significant difference between AsA at 150 and $200 \mathrm{ppm}$ doses on spike length. 
Table 3. Effect of irrigation level, ascorbic acid and their interaction on number of days till flowering, number of inflorescences/plant and inflorescence diameter of Cortaderia selloana plants during 2017/2018 and 2018/2019 seasons.

\begin{tabular}{cccccccccc}
\hline $\begin{array}{c}\text { Water level } \\
\text { (\% pot } \\
\text { capacity) }\end{array}$ & $\begin{array}{c}\text { Control } \\
(0)\end{array}$ & 100 & 150 & 200 & Mean $\begin{array}{c}\text { Control } \\
(0)\end{array}$ & 100 & 150 & 200 & $\begin{array}{c}\text { Mean } \\
\text { (A) }\end{array}$ \\
\hline
\end{tabular}

Number of days till flowering

Control (100) 421.33 c 422.67 c 432.67 a 436.00 a 428.17 a 416.00 c 417.00 c 426.33 b 430.00 a 422.33 a

$75 \quad 400.00$ d 401.33 d 427.00 b 427.00 b 413.83 b 393.67 f 396.33 e 425.00 b 430.00 a 411.25 b

$50 \quad 373.77$ e 377.00 e 421.33 c 422.33 c 398.61 c 363.67 h 366.00 g 411.00 d 411.67 d 388.08 c

Mean (B) $\quad 398.37$ b 400.33 b 427.00 a 428.44 a

391.11 d 393.11 c 420.77 b 423.89 a

\begin{tabular}{|c|c|c|c|c|c|c|c|c|c|c|}
\hline \multirow[b]{2}{*}{ Control (100) } & \multicolumn{10}{|c|}{ Number of inflorescences/plant } \\
\hline & $10.10 \mathrm{~cd}$ & $11.13 \mathrm{~b}$ & $13.23 \mathrm{a}$ & $13.33 \mathrm{a}$ & $11.95 \mathrm{a}$ & $10.63 \mathrm{c}$ & $11.73 \mathrm{~b}$ & $14.17 \mathrm{a}$ & $14.23 \mathrm{a}$ & $12.74 \mathrm{a}$ \\
\hline 75 & $8.50 \mathrm{e}$ & $9.22 \mathrm{~d}$ & $13.00 \mathrm{a}$ & $13.00 \mathrm{a}$ & $10.93 \mathrm{~b}$ & $9.00 \mathrm{e}$ & $9.60 \mathrm{~d}$ & $14.00 \mathrm{a}$ & $14.00 \mathrm{a}$ & $11.68 \mathrm{~b}$ \\
\hline 50 & $7.17 \mathrm{f}$ & $7.30 \mathrm{f}$ & $8.00 \mathrm{e}$ & $8.00 \mathrm{e}$ & $7.62 \mathrm{c}$ & $7.00 \mathrm{~g}$ & $7.00 \mathrm{~g}$ & $8.23 \mathrm{f}$ & $8.30 \mathrm{f}$ & $7.63 \mathrm{c}$ \\
\hline \multirow[t]{2}{*}{ Mean (B) } & $8.59 \mathrm{c}$ & $9.22 \mathrm{~b}$ & $11.41 \mathrm{a}$ & $11.44 \mathrm{a}$ & & $8.94 \mathrm{c}$ & $9.44 \mathrm{~b}$ & $12.13 \mathrm{a}$ & $12.22 \mathrm{a}$ & \\
\hline & \multicolumn{10}{|c|}{ Inflorescence diameter (cm) } \\
\hline Control (100) & $14.27 \mathrm{~d}$ & $14.68 \mathrm{c}$ & $16.33 \mathrm{~b}$ & $16.67 \mathrm{a}$ & $15.49 \mathrm{a}$ & $15.23 \mathrm{bc}$ & $15.33 \mathrm{~b}$ & $16.53 \mathrm{a}$ & 16.57 a & $15.92 \mathrm{a}$ \\
\hline 75 & $13.23 \mathrm{e}$ & $14.07 \mathrm{~d}$ & $16.20 \mathrm{~b}$ & $16.30 \mathrm{~b}$ & $15.95 \mathrm{~b}$ & $14.13 \mathrm{~d}$ & $14.60 \mathrm{~d}$ & $15.70 \mathrm{~b}$ & $16.50 \mathrm{a}$ & $15.23 \mathrm{~b}$ \\
\hline 50 & $12.50 \mathrm{f}$ & $13.20 \mathrm{e}$ & $14.00 \mathrm{~d}$ & $14.00 \mathrm{~d}$ & $13.43 \mathrm{c}$ & $12.80 \mathrm{f}$ & $13.53 \mathrm{e}$ & $14.47 \mathrm{~d}$ & $14.70 \mathrm{~cd}$ & $13.88 \mathrm{c}$ \\
\hline Mean (B) & $13.33 \mathrm{c}$ & $13.98 \mathrm{~b}$ & $15.51 \mathrm{a}$ & $15.66 \mathrm{a}$ & & $14.06 \mathrm{~d}$ & $14.49 \mathrm{c}$ & $15.57 \mathrm{~b}$ & $15.92 \mathrm{a}$ & \\
\hline
\end{tabular}

Means having the same letter are not significantly differed at 0.05 level of probability according to Duncan's Multiple Range Test (Duncan, 1955).

Table 4. Effect of irrigation level, ascorbic acid and their interaction on spike length and spike weight of Cortaderia selloana plants during 2017/2018 and 2018/2019 seasons.

\begin{tabular}{|c|c|c|c|c|c|c|c|c|c|c|}
\hline \multirow{3}{*}{$\begin{array}{c}\text { Water level } \\
\text { (\% pot } \\
\text { capacity) }\end{array}$} & \multicolumn{10}{|c|}{ Ascorbic acid (ppm) } \\
\hline & $\begin{array}{c}\text { Control } \\
\text { (0) }\end{array}$ & 100 & 150 & 200 & Mean & $\begin{array}{c}\text { Control } \\
\text { (0) }\end{array}$ & 100 & 150 & 200 & $\begin{array}{l}\text { Mean } \\
\text { (A) }\end{array}$ \\
\hline & \multicolumn{4}{|c|}{$2017 / 2018$} & \multicolumn{6}{|c|}{ 2018/2019 } \\
\hline & \multicolumn{10}{|c|}{ Spike length (m) } \\
\hline Control (100) & $2.22 \mathrm{c}$ & $2.29 \mathrm{~b}$ & $2.50 \mathrm{a}$ & $2.52 \mathrm{a}$ & $2.38 \mathrm{a}$ & $2.14 \mathrm{c}$ & $2.20 \mathrm{~b}$ & $2.40 \mathrm{a}$ & $2.43 \mathrm{a}$ & $2.29 \mathrm{a}$ \\
\hline 75 & $2.07 \mathrm{f}$ & $2.18 \mathrm{~d}$ & $2.47 \mathrm{a}$ & $2.51 \mathrm{a}$ & $2.31 \mathrm{~b}$ & $2.01 \mathrm{e}$ & $2.11 \mathrm{~d}$ & $2.42 \mathrm{a}$ & $2.42 \mathrm{a}$ & $2.24 \mathrm{~b}$ \\
\hline 50 & $1.67 \mathrm{i}$ & $1.78 \mathrm{~h}$ & $2.00 \mathrm{~g}$ & $2.02 \mathrm{~g}$ & 1.87 c & $1.61 \mathrm{~h}$ & $1.72 \mathrm{~g}$ & $1.93 \mathrm{f}$ & $1.94 \mathrm{f}$ & $1.80 \mathrm{c}$ \\
\hline \multirow[t]{2}{*}{ Mean (B) } & $1.98 \mathrm{c}$ & $2.08 \mathrm{~b}$ & $2.32 \mathrm{a}$ & $2.35 \mathrm{a}$ & & $1.92 \mathrm{c}$ & $2.01 \mathrm{~b}$ & $2.25 \mathrm{a}$ & $2.26 \mathrm{a}$ & \\
\hline & \multicolumn{10}{|c|}{ Spike weight (g) } \\
\hline Control (100) & $160.0 \mathrm{~d}$ & $166.0 \mathrm{c}$ & $187.0 \mathrm{~b}$ & $194.3 \mathrm{a}$ & 167.8 a & $150.0 \mathrm{~d}$ & $155.0 \mathrm{c}$ & $176.3 \mathrm{~b}$ & 182.7 a & $166.0 \mathrm{a}$ \\
\hline 75 & $137.0 \mathrm{~g}$ & $141.7 \mathrm{f}$ & 151.7 e & $162.0 \mathrm{~d}$ & $148.1 \mathrm{~b}$ & $131.0 \mathrm{~g}$ & $132.3 \mathrm{~g}$ & $141.7 \mathrm{ef}$ & $156.0 \mathrm{c}$ & $140.0 \mathrm{~b}$ \\
\hline 50 & $123.0 \mathrm{i}$ & $128.7 \mathrm{~h}$ & $131.0 \mathrm{~h}$ & $142.0 \mathrm{f}$ & $131.1 \mathrm{c}$ & $122.0 \mathrm{~h}$ & $129.0 \mathrm{~g}$ & $140.0 \mathrm{f}$ & $144.3 \mathrm{e}$ & $133.9 \mathrm{c}$ \\
\hline Mean (B) & $140.0 \mathrm{~d}$ & $145.4 \mathrm{c}$ & $156.6 \mathrm{~b}$ & $166.1 \mathrm{a}$ & & $134.0 \mathrm{a}$ & $139.0 \mathrm{c}$ & $152.7 \mathrm{~b}$ & $161.0 \mathrm{a}$ & \\
\hline
\end{tabular}

Means having the same letter are not significantly differed at 0.05 level of probability according to Duncan's Multiple Range Test (Duncan, 1955). 
The greatest values were 2.35 and 2.26 $\mathrm{m}$ for spike length and 166.1 and $161.0 \mathrm{~g}$ for spike weight in both seasons, respectively.

Regarding the effect of the interaction between irrigation levels and AsA application (Table, 4), data showed that applying AsA at 150 or 200 ppm recorded similar significant results in plants watered with either control (100\% PC) or $75 \%$ PC. The highest values were 2.52 and $2.43 \mathrm{~m}$ for spike length and 194.3 and $182.7 \mathrm{~g}$ for spike weight in both seasons, respectively, for plants watered with 100\% PC (control) and treated with AsA at $200 \mathrm{ppm}$.

\section{Chemical compositions:}

For irrigation levels effect, data in Table (5) refers to a decrease in total carbohydrates and chlorophyll contents by decreasing water amount, the highest values of these component were recorded when plants were irrigated at $100 \%$ PC giving $29.75 \%$ D.W. for total carbohydrates and $1.51 \mathrm{mg} / \mathrm{g} \mathrm{F.W}$. for total chlorophylls).

Regarding the effect of ascorbic acid application, the increase in AsA doses caused an increment in total carbohydrates and chlorophylls contents, reaching the highest values (28.06 \% D.W. for total carbohydrates and $1.57 \mathrm{mg} / \mathrm{g} \mathrm{F.W}$. for total chlorophylls) in plants sprayed with AsA at 200 ppm.
Data in Table (5) also show that AsA applications significantly reduce the negative effect of water deficit. The highest values for total carbohydrates and chlorophylls were $34.25 \%$ and $1.73 \mathrm{mg} / \mathrm{g}$, respectively for plants irrigated with $100 \%$ PC and sprayed with AsA at $200 \mathrm{ppm}$.

Data in Fig. (2) clear that growing plants under water shortage markedly increased the accumulation in proline; and irrigation level at $50 \%$ PC resulted in the highest content (0.83 mg/g D.W.).

Data in Fig. (2) also show that foliar application with AsA increased leaves proline content. The highest value was 0.78 $\mathrm{mg} / \mathrm{g}$ D.W. for plants received AsA at 200 ppm.

Referring to the interaction between irrigation levels and AsA application data in Fig. (2) clear that AsA increased proline content according to the decrease in irrigation levels, reaching the maximum value $(0.92 \mathrm{mg} / \mathrm{g}$ D.W. $)$ for plants watered with 50\% PC and treated with AsA at 200 ppm.

\section{DISCUSSION}

The previous results dealt with treating seedlings of Cortaderia selloana with ascorbic acid under drought stress. Drought stress had significant negative effects on growth and physiological traits.

Table 5. Effect of irrigation level, ascorbic acid and their interaction on total carbohydrate and total chlorophylls of Cortaderia selloana plants during 2018/2019 seasons.

\begin{tabular}{cccccccccccc}
\hline $\begin{array}{c}\text { Water level } \\
\text { (\% pot } \\
\text { capacity) }\end{array}$ & $\begin{array}{c}\text { Control } \\
(\mathbf{0})\end{array}$ & $\mathbf{1 0 0}$ & $\mathbf{1 5 0}$ & $\mathbf{2 0 0}$ & Mean & $\begin{array}{c}\text { Control } \\
\mathbf{( 0 )}\end{array}$ & $\mathbf{1 0 0}$ & $\mathbf{1 5 0}$ & $\mathbf{2 0 0}$ & $\begin{array}{c}\text { Mean } \\
\text { (A) }\end{array}$ \\
\hline \multicolumn{8}{c}{ Total carbohydrate (\% D.W.) } & \multicolumn{5}{c}{ Total chlorophylls (mg/g F.W.) } \\
Control (100) & $25.40 \mathrm{~d}$ & $27.60 \mathrm{c}$ & $31.74 \mathrm{~b}$ & $34.25 \mathrm{a}$ & $29.75 \mathrm{a}$ & $1.33 \mathrm{e}$ & $1.43 \mathrm{~d}$ & $1.54 \mathrm{c}$ & $1.73 \mathrm{a}$ & $1.51 \mathrm{a}$ \\
$\mathbf{7 5}$ & $21.57 \mathrm{~g}$ & $23.57 \mathrm{e}$ & $25.37 \mathrm{~d}$ & $27.78 \mathrm{c}$ & $24.57 \mathrm{~b}$ & $1.31 \mathrm{e}$ & $1.33 \mathrm{e}$ & $1.51 \mathrm{c}$ & $1.65 \mathrm{~b}$ & $1.45 \mathrm{~b}$ \\
$\mathbf{5 0}$ & $18.06 \mathrm{i}$ & $20.30 \mathrm{~h}$ & $21.80 \mathrm{fg}$ & $22.13 \mathrm{f}$ & $20.71 \mathrm{c}$ & $1.08 \mathrm{~h}$ & $1.14 \mathrm{~g}$ & $1.24 \mathrm{f}$ & $1.34 \mathrm{e}$ & $1.19 \mathrm{c}$ \\
$\mathbf{5 0}$ & $21.86 \mathrm{~d}$ & $23.82 \mathrm{c}$ & $26.30 \mathrm{~b}$ & $28.06 \mathrm{a}$ & & $1.24 \mathrm{~d}$ & $1.30 \mathrm{c}$ & $1.43 \mathrm{~b}$ & $1.57 \mathrm{a}$ & \\
\hline
\end{tabular}

Means having the same letter are not significantly differed at 0.05 level of probability according to Duncan's Multiple Range Test (Duncan, 1955). 


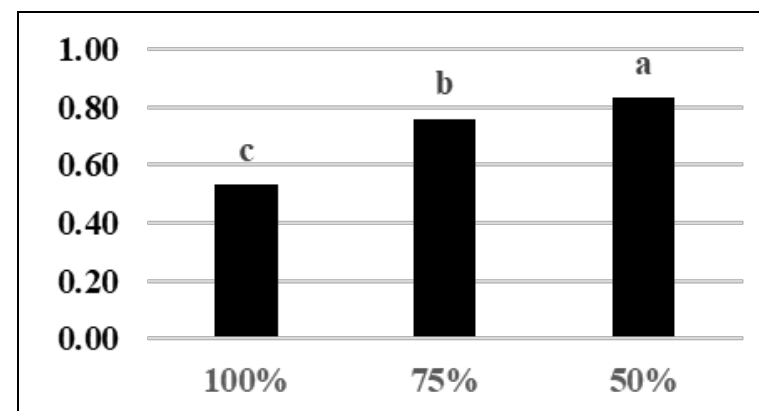

Water levels

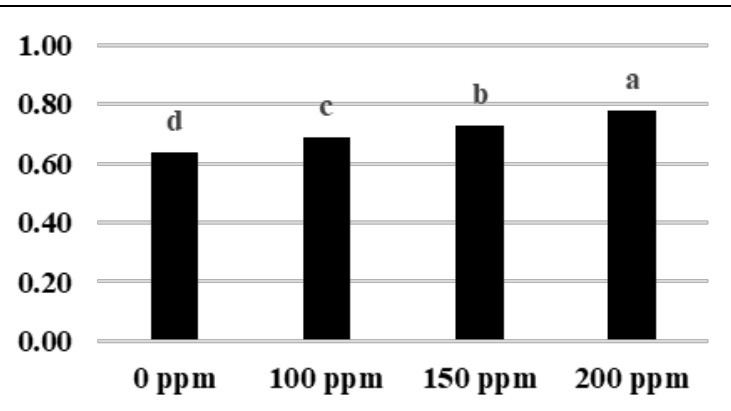

Ascorbic acid

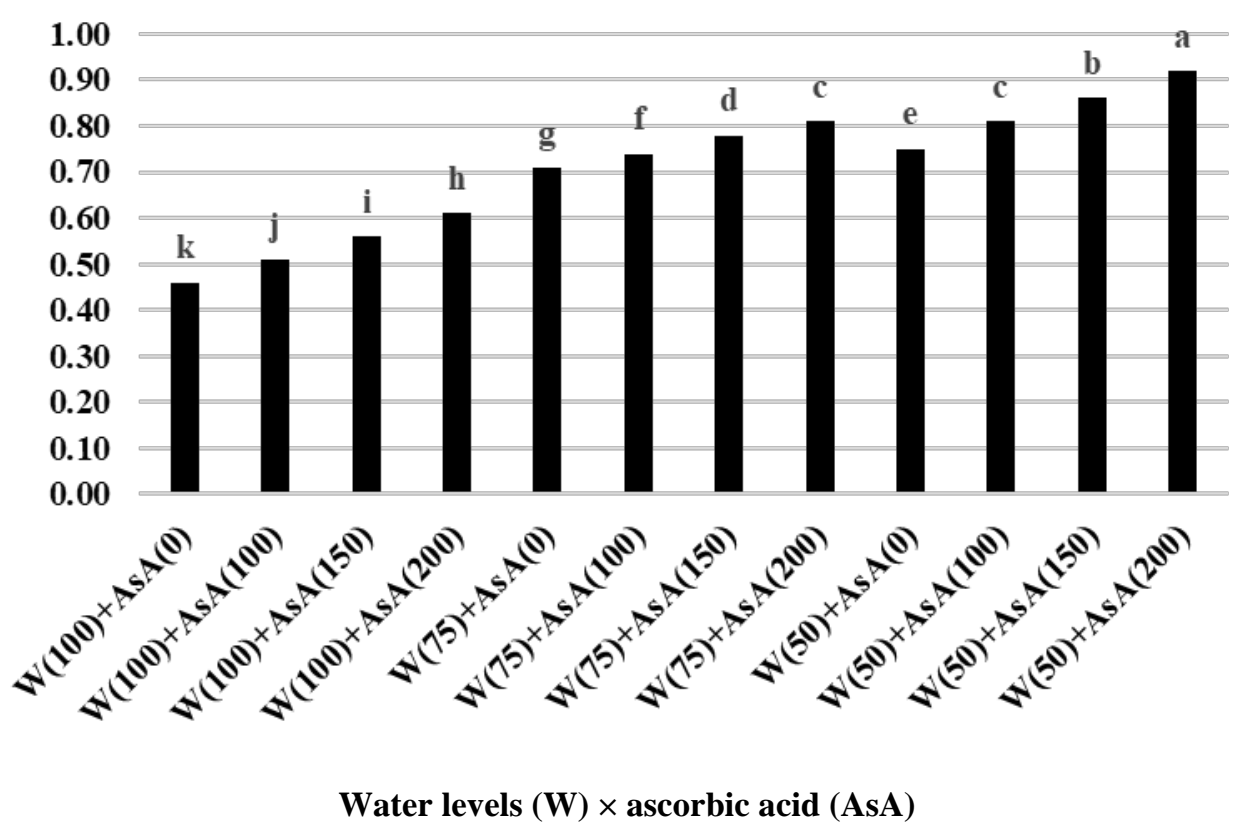

Fig. 2. Effect of water levels, ascorbic acid and their interaction on leaves proline content (mg/g D.W.) of Cortaderia selloana plants during 2018/2019 season.

Means having the same letter are not significantly differed at 0.05 level of probability according to Duncan's Multiple Range Test (Duncan, 1955).

Growth parameters and chemical composition improved upon using ascorbic acid, as foliar application of AsA decreased the negative effects of drought.

These results were in accordance with findings of many other researchers demonstrated in the following discussion:

Observed decreases in biomass with decreased irrigation quantities are well documented. Guenni et al. (2002) recorded a reduction in dry weight for Brachiaria brizantha when subjected to moderate drought stress. Alvarez et al. (2007) stated that plant mass, canopy size, root biomass and shoot-to-root ratios increased with increasing irrigation volumes for purple love grass (Eragrostis spectabilis) and Miscanthus sinensis. Zhi et al. (2007) reported that the proline content increased in zebra grass (Miscanthus sinensis), fountain grass (Pennisetum alopecuroides) and pampas grass (Cortaderia selloana) under drought stress.

These results were corresponded with those findings by Amin et al. (2009) and Abdalla (2011), which reported that plant growth reduced by water deficit stress through affecting various physiological and biochemical processes, such as photosynthesis, translocation, nutrient metabolism and growth promoters. Riaz et al. (2010) indicated that water deficit 
conditions had a significant inhibitory effect on shoot length, fresh and dry weights of three Bermuda grass cultivars. Water deficiency also reduced the total chlorophylls, significantly in all cultivars and it was most pronounced at 55\% F.C.

Furthermore, AsA affects nutritional cycle's activity in higher plants and plays an important role in the electron transport system (Liu et al., 1997). It is also important as a cofactor for a large number of key enzymes in plants (Arrigoni and De Tullio, 2000). Exogenous application of ascorbic acid increased reproduction of other plant species as reported by Balbaa (2002) on Tagetes minuta L., Youssef and Talaat (2003) on rosemary and Abd El-Aziz et al., (2007) on syngonium. Abd El-Aziz and Taha (2009) on gladiolus reported that the highest increase in plant height, number of leaves, fresh and dry weights of leaves were found in plants treated with $100 \mathrm{ppm}$ ascorbic acid compared with control. Mazher et al. (2011) demonstrated that foliar application of ascorbic acid on Codiaeum variegatum at (100 and 200 ppm) gradually increased all growth parameters (plant height, number of branches, number of leaves, stem diameter, root length as well as fresh and dry weights of all plant organs) and as well as the content of the total carbohydrates. Sardoei et al. (2014) found that spraying Gazania rigens with ascorbic acid had a significant effect on increasing total of flowers/plant and prolonging duration of flowering period.

The role of ascorbate in proline synthesis was explained from some reports. For example, Rana et al. (2017) reported that AsA might be essential for hydroxyproline synthesis, a non-essential amino acid derivative. Likewise, ascorbate is also essential for collagen synthesis, especially the hydroxylation of prolyl residues. The beneficial effects on plant survival rate, biomass, shoot, and root growth by exogenous AsA have been reported under water stress (Shalata and Neumann, 2001; Athar et al., 2008). Khan et al. (2006) on wheat showed that ascorbic acid at the rate of $100 \mathrm{ppm}$ reduced the adverse effects of drought stress. Xu et al. (2015) stated that treating Festuca arundinacea roots with ascorbic acid could mitigate root growth decline due to water stress attributed these effects to its role in activating non-enzymatic or enzymatic antioxidant systems.

The results of the studies by Malik et al. (2015) showed that application of ascorbic acid under drought could overcome adverse effects of oxidative stress by maintaining growth, relative water content, osmotic adjustment through proline accumulation and by enhanced activity of antioxidant enzymes. Abd-Elmoneim et al. (2018) stated that Euphorbia milii var. Longifolia plants treated with AsA gained the highest records of plant height, stem length, leaf length, fresh weight of leaves, stem fresh and dry weights and total chlorophyll content under water stress. Farooq et al. (2020) also found that water stress significantly decreased the shoot and root fresh and dry weights, shoot and root lengths and chlorophyll content in four safflower cultivars, while it increased the leaf free proline. While foliar-applied (100 mg/l and $150 \mathrm{mg} / \mathrm{l}$ ) ascorbic acid caused a marked improvement in shoot and root fresh and dry weights, plant height, and chlorophyll content and also increased the accumulation of leaf proline.

\section{REFERENCES}

Abd El-Aziz, Nahed G.; El-Quesni, Fatma E.M. and Farahat, M.M. (2007). Response of vegetative growth and some chemical constituents of Syngonium podophyllum L. to foliar application of thiamine, ascorbic acid and kinetin at Nubaria. World J. Agric. Sci., 3(3):301305.

Abd El-Aziz, Nahed G. and Taha, S.S. (2009). Some studies on the effect of putrescine, ascorbic acid and thiamine on growth, flowering and some chemical constituents of gladiolus plants at Nubaria. Ozean Journal of Applied Sciences 2(2):169-179. 
Abdalla, M.M. (2011). Beneficial effects of diatomite on the growth, the biochemical contents and polymorphic DNA in Lupinus albus plants grown under water deficit stress. Agric. Biol. J. North Amer., 2(2):207-220.

Abd-Elmoneim, A.; Abdul-Moneem, N. and Ibrahim, A. (2018). The effect of watering regimes and bio and chemical treatments on flowering of Euphorbia milii var. Longifoia plants. Scientific Journal of Flowers and Ornamental Plants, 5(4):323-346.

Alvarez, E; Scheiber, S.M.; Beeson, R.C. and David, D.R. (2007). Drought tolerance responses of purple love grass and 'Adagio' Maiden Grass. Hort. Science, 42(7):1695-1699.

Amin, B.; Mahleghah, G.; Mahmood, H.M.R. and Hossein, M. (2009). Evaluation of interaction effect of drought stress with ascorbate and salicylic acid on some of physiological and biochemical parameters in okra (Hibiscus esculentus L.). Res. J. Biol. Sci., 4(4): 380-387.

Khan, A; Ahmed, M.S.A.; Athar, H.U.R. and Ashraf, M. (2006). Interactive effect of foliarly applied ascorbic acid and salt stress on wheat (Triticum aestivum L.) at the seedling stage. Pakistan J. Bot., 38(5):1404-1414.

Arrigoni, O. and De Tullio, M.C. (2000). The role of ascorbic acid in cell metabolism: between gene-directed functions and unpredictable chemical reactions. J. Plant Physiol., 157(5):481488.

Ashraf, M. (2009). Biotechnological approach of improving plant salt tolerance using antioxidants as markers. Biotechnol. Adv., 27(1):84-93.

Athar, H.U.R.; Khan, A. and Ashraf, M. (2008). Exogenously applied ascorbic acid alleviates salt-induced oxidative stress in wheat. Environ. Exp. Bot., 63(13):224-231.
Balbaa, L.K. (2002). Physiological effect of ascorbic acid and kinetin on growth and chemical constituents of Tagetes minuta L. Egypt. J. Appl. Sci., 17(7):249-267.

Bates, L.S.; Walden, R.P. and Teare, T.D. (1973). Rapid determination of free proline for water stress studies. Plant and Soil, 39:305-307.

Brown, L.V. (2002). Applied Principles of Horticultural Science, Second Edition. Butterworth-Heinemann, UK, 322 p.

Chai, Q.; Gan, Y.; Zhao, C.; Xu, H.L.; Waskom, R.M.; Niu, Y. and Siddique, K.H.M. (2015). Regulated deficit irrigation for crop production under drought stress. A review. Agron. Sustain. Dev. 36:3. Https://doi.org/10.1007/ s13593-015-0338-6

Conklin, P.L. and Barth, C. (2004). Ascorbic acid, a familiar small molecule intertwined in the response of plants to ozone, pathogens, and the onset of senescence. Plant Cell Environ., 27(8):959-970.

Dolatabadian, A.; Sanavy, S.A.M. and Asilan, K.S. (2010). Effect of ascorbic acid foliar application on yield, yield component and several morphological traits of grain corn under water deficit stress conditions. Not. Sci. Biol., 2(3):4550 .

Dubois, M.; Gilles, K.A.; Hamilton, J.K.; Rebers, P.T. and Smith, F. (1956). Colorimetric method for determination of sugars and related substances. Analytical Chemistry, 28(3):350-356.

Duncan, D.B. (1955). Multiple range and multiple F test. Journal of Biometrics, 11:142.

Farooq, A.; Bukhari, S.A.; Akram, N.A.; Ashraf, M.; Wijaya, L.; Alyemeni, M. N. and Ahmad, P. (2020). Exogenously applied ascorbic acid-mediated changes in osmoprotection and oxidative defense system enhanced water stress tolerance in different cultivars of safflower (Carthamus tinctorious L.). Plants 
(Basel, $\quad$ Switzerland), 9(1):104. doi:10.3390/plants9010104

Gomez, K.A. and Gomez, A.A. (1984). Statistical Procedures for Agricultural Research. John Wiley \& Sons, New York, USA, 680 p.

Guenni, O.; Marin, D. and Baruch, Z. (2002). Responses to drought of five Brachiaria species, I. Biomass production, leaf growth, root distribution, water use and forage quality. Plant and Soil, 243(2):229-241.

Hameed, A.; Hussain T.; Gulzar, S.; Aziz, I.; Gul, B. and Khan, M.A. (2012). Salt tolerance of a cash crop halophyte Suaeda fruticosa: biochemical responses to salt and exogenous chemical treatments. Acta Physiol. Plant., 34:2331 2340.

Hemavathi, C.P.; Upadhyaya, N.; Akula, H.S.; Kim, J.H.; Jeon, M.H.; Oh, S.C.; Chun, D.H.K. and Park, S.W. (2011). Biochemical analysis of enhanced tolerance in transgenic potato plants overexpressing d-galacturonic acid reductase gene in response to various abiotic stresses. Mol. Breed., 28(1):105115.

Inzé, D. and Van Montagu, M. (1995). Oxidative stress in plants. Curr. Opin. Biotechnol., 6(2):153-158.

Larkindale, J.; Hall, J.D.; Knightand, M.R. and Vierling, E. (2005). Heat stress phenotypes of Arabidopsis mutants implicate multiple signaling pathways in the acquisition of thermo-tolerance. Plant Physiol., 138(2):882-897.

Liu, W.; Hu, W.Y.; Hao, J.J. and Chen, G. (1997). The relationship between ascorbic acid and changes of several physiological and biochemical indexes in isolated wheat leaves under $\mathrm{NaCl}$ stress. Plant Physiol. Communications., 33(6): 423-425.

Malik, S.; Ashraf1, M.; Arshad, M. and Malik, T.A. (2015). Effect of ascorbic acid application on physiology of wheat under drought stress. Pak. J. Agri. Sci., 52(1):209-217.

Masih, I.; Maskey, S.; Mussá, F.E.F. and Trambauer, P.A. (2014). Review of droughts on the African continent: A geospatial and long-term perspective. Hydrol. Earth Syst. Sci., 18(9):36353649.

Mazher, A.A.M.; Zaghloul, S.M.; Mahmoud, S. A. and Siam, H.S. (2011). Stimulatory effect of kinetin, ascorbic acid and glutamic acid on growth and chemical constituents of Codiaeum variegatum L. plants. American-Eurasian J. Agric. \& Environ. Sci., 10(3):318-323.

Mittler, R. (2002). Oxidative stress, antioxidants and stress tolerance. Trends Plant Sci., 7(9):405-410.

MSTAT Development Team (1989). MSTAT user's guide: a microcomputer program for the design management and analysis of agronomic research experiments. Michigan State University, East Lansing, USA, 496 p.

Noctor, G. and Foyer, C.H. (1998). Ascorbate and glutathione: keeping active oxygen under control. Ann. Rev. Plant Physiol. Plant. Mol. Biol., 49:249 279.

Oakes, A.J. (1990). Ornamental Grasses and Grass-like Plants. Van Nostrand Reinhold, New York, USA, 614 p.

Rana, V.; Ram, S. and Nehra, K. (2017). Review proline biosynthesis and its role in abiotic stress. Int. J. Agric. Innov. Res., 6(3):2319-2473.

Razaji A.; Asli, D.E. and Farzanian, M. (2012). The effects of seed priming with ascorbic acid on drought tolerance and some morphological and physiological characteristics of safflower (Carthamus tinctorius L.). Ann. Biol. Res., 3(8):39843989.

Riaz, A.; Adnan, Y.; Hameed, M. and Kiran, S. (2010). Morphological and biochemical responses of turf grasses to 
water deficit conditions. Pakistan Journal of Botany, 42(5):3441-3448.

Sardoei, S.A.; Shahdadneghad, M.; Yazdi, R.M. and Mohammadi, T. (2014). Effects of zinc sulphate and ascorbic acid on flowering characteristics of ornamental plant gazania (Gazania rigens) cv. Daybreak Red Stripe. International J. of Adv. Biolog. and Biomed. Res., 2(2):392-398.

Shafiq, S.; Akram, N.A.; Ashraf, M. and Arshad, A. (2017). Synergistic effects of drought and ascorbic acid on growth, mineral nutrients and oxidative defense system in canola (Brassica napus L.) plants. Acta Physiol. Plant. 36(6):15391553.

Shalata, A.; and Neumann, P.M. (2001). Exogenous ascorbic acid (vitamin C) increases resistance to salt stress and reduces lipid peroxidation. J. Exp. Bot., 52(364):2207-2211.

Sun, Y.; Niu, G. and Perez, C. (2015). Relative salt tolerance of seven Texas superstar perennials. HortScience, 50(10):1562-1566.

Talla, S.; Riazunnisa, K. Padmavathi, L.; Sunil, B.; Rajsheel, P. and Raghavendra, A.S. (2011). Ascorbic acid is a key participant during the interactions between chloroplasts and mitochondria to optimize photosynthesis and protect against photoinhibition. J. Biosci., 36(1):163-173.

Venkatesh, J.; Upadhyaya, C.P.; Yu, J.W.; Hemavathi, A.; Kim. D.H.; Strasser, R.J. and Park, S.W. (2012). Chlorophyll a fluorescence transient analysis of transgenic potato overexpressing Dgalacturonic acid reductase gene for salinity stress tolerance. Hort. Environ. Biotechnol., 53(4):320-328.

Vurukonda, S.S.K.P.; Vardharajula, S.; Shrivastava, M. and Skz, A. (2016). Enhancement of drought stress tolerance in crops by plant growth promoting rhizobacteria. Microbiol. Res., 184:1324.
Wang, W.; Vinocur, B. and Altman, A. (2003). Plant responses to drought, salinity and extreme temperatures: towards genetic engineering for stress tolerance. Planta., 218(1):1-14.

Wellburn, A.R. and Lichtenthaler, H. (1984). Formulae and program to determine total carotenoids and chlorophylls-a and b of leaf extracts in different solvents, Adv. Agricul. Biotechn., 2(1):9-12.

Wolucka, B.A.; Goossens, A. and Inzé, D. (2005). Methyl jasmonate stimulates the de novo biosynthesis of vitamin $C$ in plant cell suspensions. J. Exp. Bot., 56(419):2527-2538.

Xu, Y.; Xu, Q. and Huang, B. (2015). Ascorbic acid mitigation of water stressinhibition of root growth in association with oxidative defense in tall fescue (Festuca arundinacea Schreb.). Frontiers in Plant Science, 6:807. doi: 10.3389/fpls.2015.00807

Youssef, A.A. and Talaat, I.M. (2003). Physiological response of rosemary plants to some vitamins. Egypt. Pharm. J., 1(1):81-93.

Zhang, C.; Liu, J.; Zhang, Y.; Cai, X.; Gong, P.; Zhang, J.; Wang, T.; Li, H. and Ye, Z. (2011). Overexpression of SlGMEs leads to ascorbate accumulation with enhanced oxidative stress, cold, and salt tolerance in tomato. Plant Cell Rep., 30(3):389398.

Zhang, L.; Wang, Z.; Xia, Y.; Kai, G.; Chen, W. and Tang, K. (2007). Metabolic engineering of plant L-ascorbic acid biosynthesis: recent trends and applications. Crit. Rev. Biotechnol. 27(3):173-182.

Zhi, Z.; Xia, Y.; Chang, L. and Sun, X. (2007). Relationship between physiological changes and drought tolerance in three species of ornamental grasses under drought stress. Journal of Northeast Forestry University, 12:17-20. 


\section{تحسين قدرة نباتات الكورتادريا سيلوانا على تحمل نقص ماء الري باستخدام حمض الاسكوربيك}

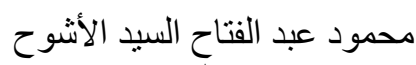

قسم بحوث الزينة وتتسيق الحدائق، معهد بحوث البساتين، مركز البحوث البنوح الزراعية، الجيزة، مصر

من أجل تحسين قدرة شتلات Cortaderia selloana على تحمل نقص مباه الري، أجريت الدراسة الحالية في

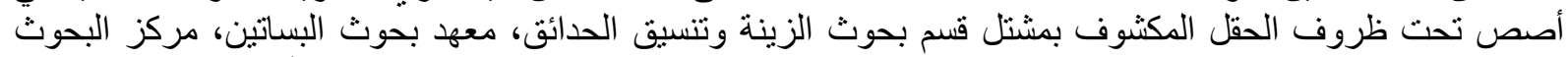

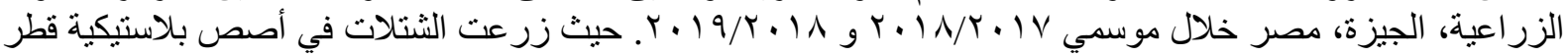

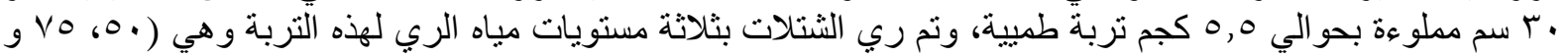

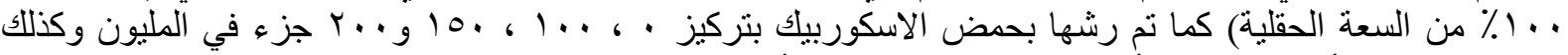

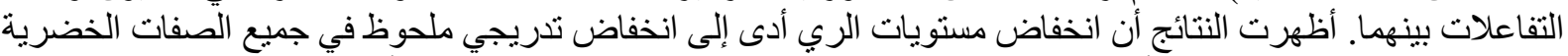

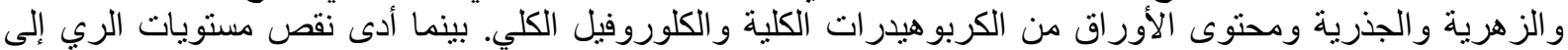

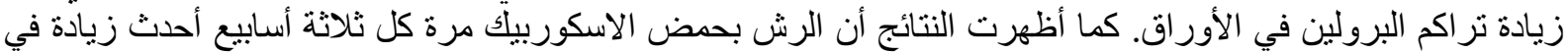

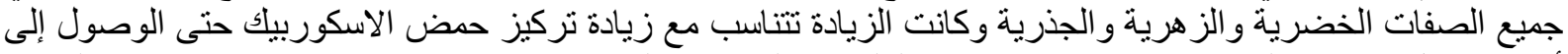

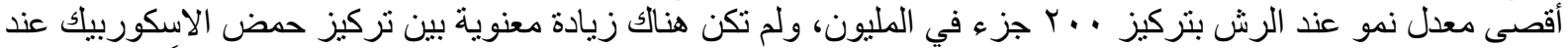

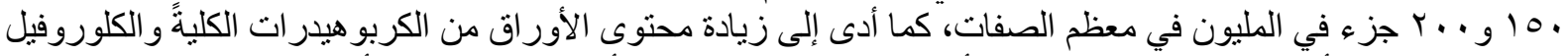

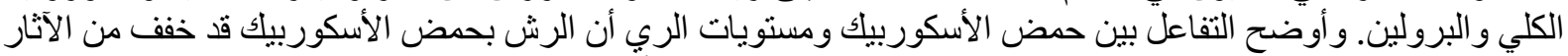

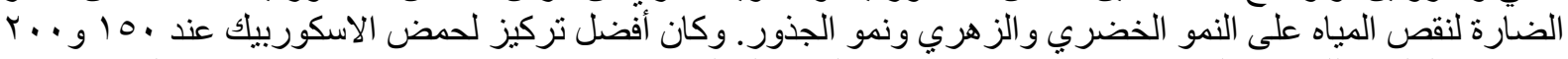

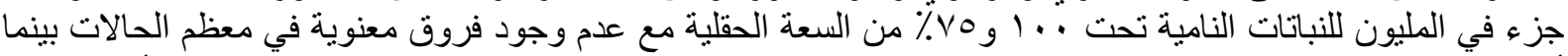

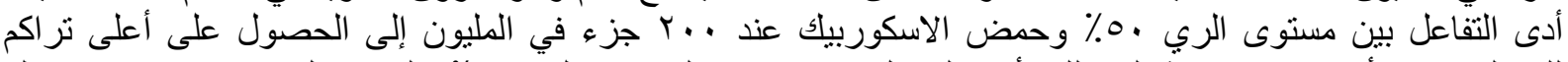

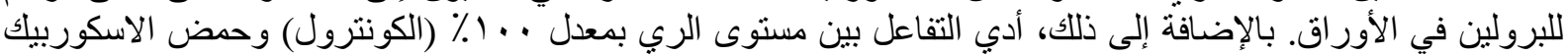

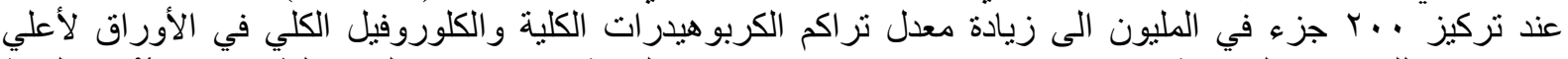

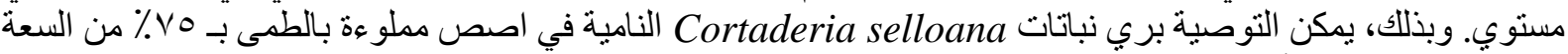

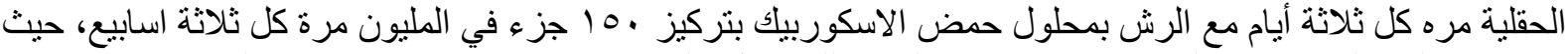

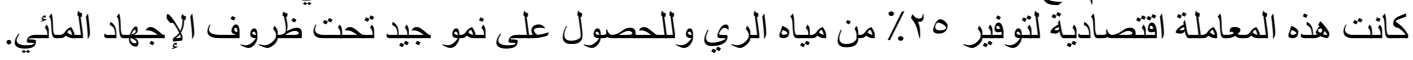


